\title{
ANALISIS PERBANDINGAN KINERJA PADA BANK NASIONAL, BANK CAMPURAN, DAN BANK ASING YANG TERDAFTAR DI BURSA EFEK INDONESIA
}

\author{
Christania Graciella Angel \\ (e-mail : gangel_140890@yahoo.co.id)
}

\begin{abstract}
Bank performance appraisal is based on bank financial report itself. The financial report can be form balance report which give information about the financial position to the outside of bank that can be used of eksternal to assess the level of risk exist in a bank. Based on ownership consist of national bank, mixture bank and foreign bank. These banks has tight compete to show a good performance to the public. This research aimed to analyze the financial performance difference of national bank and foreign bank at the period of 2004 to 2013 with the proxy finance ratio (CAMEL ratio) consist of: Capital, Asset Quality, Management, Earnings, and Liquidity. The population in this research consist of national bank, mixture bank, and foreign bank listed on the Indonesia Stock Exchange at the period of 2004 to 2013 which amount 42 banks. Based on purposive sampling techniques, the number of samples that meet the criteria are as many as 15 banks (5 national banks, 5 mixture banks, and 5 foreign banks). Analysis technique that use in this research is $t$-test. As the result the usage of proxy CAMEL ratio to analyze comparison bank performance give evidence that mixture bank performance is better than foreign bank and national bank performance.
\end{abstract}

Keywords : financial performance, national bank, foreign bank, CAMEL ratio.

\section{PENDAHULUAN}

\section{Latar Belakang}

Perekonomian Indonesia yang semakin terpuruk dewasa ini, seperti yang terlihat dari pertumbuhan ekonomi yang rendah, telah mengakibatkan persaingan antar perusahaan semakin ketat, khususnya bagi perusahaan yang memproduksi barang sejenis. Akibat positif dari persaingan ini adalah munculnya dorongan agar perusahaan meningkatkan daya saingnya, seperti dalam hal kualitas produk, kualitas pelayanan, efisiensi dan sebagainya. Salah satu bidang usaha yang menunjukkan persaingan yang ketat adalah bisnis perbankan.

Dampak krisis moneter yang terjadi mulai tahun 1997 terhadap industri perbankan di Indonesia adalah terjadinya negative-spread yaitu semakin besar perbedaan negatif antara sources dan uses of fund dan banyaknya debitur yang tidak mampu lagi membayar kewajibannya karena tingginya loan interest rate, mengakibatkan menurunnya kinerja perbankan di Indonesia. Sehingga banyak Bank Umum Swasta Nasional yang terkena penalti dari yang berbentuk take over sampai likuidasi (beku operasi) (Soendoro,2001). Penurunan kinerja bank-bank tersebut harus segera diperbaiki karena jika penurunan kinerja tersebut terus berlanjut tentunya akan membuat kredibilitas perbankan di mata masyarakat akan semakin menurun dan bagi bank-bank yang mengalami penurunan kinerja secara tajam tentu tinggal menunggu waktu untuk dilikuidasi jika tidak ada upaya untuk memperbaiki kinerjanya. Penilaian terhadap kinerja bank dapat dilakukan dengan melakukan analisis laporan keuangannya.

Ketentuan pelaksanaan penilaian tingkat kesehatan bank perlu diatur, sehubungan dengan hal tersebut penilaian mencakup faktor-faktor CAMEL yang terdiri dari: Permodalan (Capital), Kualitas Aset (Asset Quality), Manajemen (Management), Rentabilitas (Earnings), Likuiditas (Liquidity). Masalah yang timbul dalam penelitian ini :

1. Apakah terdapat perbedaan kinerja keuangan antara bank nasional dan bank asing yang terdaftar di BEI periode tahun 2004-2013?

2. Apakah terdapat perbedaan kunerja keuangan antara bank nasional dan bank campuran yang terdaftar di BEI periode tahun 2004-2013?

3. Apakah terdapat perbedaan kinerja keuangan antara bank asing dan campuran yan g terdaftar di BEI periode tahun 2004-2013? 


\section{Tujuan Penelitian}

1. Untuk menganalisis perbedaan kinerja keuangan antara bank nasional dan bank asing yang terdaftar di BEI periode tahun 2004-2013.

2. Untuk menganalisis perbedaan kinerja keuangan antara bank nasional dan bank campuran yang terdaftar di BEI periode tahun 2004-2013.

3. Untuk menganalisis perbedaan kinerja keuangan antara bank campuran dan bank asing yang terdaftar di BEI periode tahun 2004-2013.

\section{TINJAUAN PUSTAKA \\ Landasan Teori}

Good corporate governance (GCG) merupakan praktik terbaik yang biasa dilakukan oleh suatu perusahaan yang berhasil yang mengacu pada bauran antara alat, mekanisme, dan struktur yang menyediakan kontrol dan akuntabilitas yang dapat meningkatkan kinerja perusahaan. Praktik terbaik ini mencakup praktik bisnis, aturan main, struktur proses, dan prinsip yang dimiliki. Perusahaan dengan praktik Corporate Governance yang baik akan dapat meningkatkan nilai perusahaan bagi pemegang saham karena visi, misi dan strategi perusahaan dinyatakan dengan jelas, nilai-nilai perusahaan serta kode etik disusun untuk memastikan adanya kepatuhan seluruh jajaran perusahaan, terdapat kebijakan untuk menghindari benturan kepentingan dan transaksi dengan pihak ketiga yang tidak tepat, risiko perusahaan dikelola dengan baik dan terdapat sistem pengendalian dan monitoring yang baik (Solomon, 2003).

Terdapat lima prinsip corporate governance yang melandasi beberapa riset tentang pengukuran tingkat penerapan corporate governance pada perusahaan. Kelima prinsip tersebut adalah sebagai berikut.

1. Menjamin kerangka dasar Corporate Governance yang efektif.

2. Hak-hak Pemegang Saham dan Fungsi-fungsi Penting Kepemilikan Saham.

3. Perlakuan yang sama terhadap pemegang saham.

4. Peranan Stakeholders dalam Corporate Governanace.

5. Keterbukaan dan Transparansi.

Bank merupakan lembaga keuangan yang fungsi pokoknya memberikan kredit dan jasa-jasa dalam lalu lintas pembayaran dan peredaran uang. Oleh karena itu bank mempunyai ruang lingkup usaha yang luas. Pengertian bank menurut Undang-Undang Republik Indonesia No. 10 tahun 1998 tentang perbankan : (1) Pasal 1, perbankan adalah segala sesuatu yang menyangkut tentang bank, yang mencakup kelembagaan, kegiatan usaha, serta cara dan proses dalam melaksanakan kegiatan usahanya.; (2) Pasal 2, bank adalah badan usaha yang menghimpun dana dari masyarakat dalam bentuk simpanan dan menyalurkan kepada masyarakat dalam bentuk kredit dan atau bentuk-bantuk lainnya dalam rangka meningkatkan taraf hidup orang banyak; (3) Pasal 3, bank umum adalah bank yang melaksanakan kegiatan usaha secara konvensional dan atau berdasarkan prinsip syariah yang dalam kegiatannya memberikan jasa dalam lalu lintas pembayaran; (4) Pasal 4, Bank Perkreditan Rakyat adalah bank yang melaksanakan kegiatan usaha secara konvensional atau berdasarkan prinsip syariah yang kegiatannya tidak memberikan jasa dalam lalu lintas pembayaran.

Bank asing adalah bank umum yang didirikan dan dimiliki oleh pengusaha asing. Bank asing hanya dapat didirikan dan menjalankan usahanya sebagai bank setelah mendapat ijin usaha dari menteri keuangan. Bank ini didirikan dalam bentuk cabang dari bank yang sudah ada di luar negeri atau suatu bank asing dan bank nasional di Indonesia yang berbadan hukum Indonesia dan berbentuk Perseroan Terbatas.

Bank nasional terdiri dari bank-bank milik negara yang terdiri dari dari bank sentral dan bank umum milik negara, bank-bank milik pemerintah daerah yaitu bank-bank pembangunan daerah yang terdapat pada setiap Daerah Tingkat I, dan bank-bank milik swasta nasional yaitu bank-bank seluruh sahamnya dimiliki warga negara Indonesia dan atau badan-badan hukum yang peserta dan pemimpinnya terdiri atas warga negara Indonesia Suyatno (2007).

Analisis Rasio Finansial (Financial Statements Analysis) adalah alat-alat analisis yang digunakan untuk mengukur kinerja perusahaan di bidang keuangan. Analisa rasio memperhatikan kepada perhitungan rasio agar dapat mengevaluasi keadaan finansial pada masa yang lalu, sekarang dan memproyeksikan hasil yang akan datang. Rasio dapat dihitung berdasarkan financial statement yang telah 
tersedia yang terdiri dari : a) Balance sheet atau neraca, yang menunjukkan posisi perusahaan pada suatu saat. b) Income statement atau rugi laba yang merupakan laporan operasi perusahaan selama periode tertentu. Untuk mengetahui sejauh mana kondisi finansial perusahaan saat ini, diperlukan suatu cara evaluasi diantaranya; analisis historis (historical analysis) yang merupakan perkembangan antara suatu rasio saat sekarang dengan rasio yang sama pada waktu yang lampau, dan rasio industri yang merupakan rata-rata rasio yang dihasilkan dari beberapa perusahaan yang sejenis yang dapat dijadikan pembanding bagi perusahaan yang bersangkutan.

Penilaian tingkat kesehatan bank mencakup faktor-faktor CAMEL yang terdiri dari:

1. Permodalan (Capital Adequacy Ratio / CAR)

CAR merupakan rasio permodalan yang menunjukkan kemampuan bank dalam rangka pengembangan usaha dan menampung kemungkinan resiko kerugian yang diakibatkan kegiatan operasional bank. Penilaian aspek ini lebih dimaksudkan untuk mengetahui bagaimana atau berapa modal bank tersebut telah memadai untuk menunjang kebutuhannya. Apabila CAR perusahaan perbankan cukup tinggi, hal tersebut menunjukkan bahwa perusahaan perbankan tersebut memiliki kecukupan modal, sehingga kepercayaan masyarakat akan semakin meningkat. Apabila perusahaan perbankan telah go public, peningkatan kepercayaan itu tercermin melalui kenaikan harga sahamnya. Peningkatan harga saham akan meningkatkan nilai perusahaan dan return saham. Berdasarkan hal ini tampak hubungan yang signifikan antara CAR dengan resiko investasi pada saham perbankan. Perhitungan penyediaan modal minimum (CAR) didasarkan pada prinsip bahwa setiap penanaman dana bank yang mengandung resiko harus disediakan jumlah modal sebesar presentase tertentu dari jumlah penanamannya.

2. Kualitas Aset (Asset Quality)

Aktiva produktif merupakan sumber pendapatan utama dari kegiatan perusahaan perbankan. Yang termasuk komponen aktiva produktif di sini adalah kredit yang diberikan, penanaman modal dalam surat berharga, penanaman modal ke bank lain dan penyertaan. Pendapatan bank diharapkan semakin besar dari penanaman dalam aktiva produktif, sehingga kesempatan untuk memperoleh laba semakin meningkat. Perolehan laba akan memberikan penilaian positif bagi investor yang menanamkan modalnya pada saham perbankan. Dana yang berhasil dihimpun oleh bank akan menjadi beban bila dibiarkan saja. Oleh sebab itu bank harus mengalokasikan dananya dalam bentuk aktiva produktif. Penanaman dana bank pada aktiva produktif wajib dilaksanakan berdasarkan prinsip kehati-hatian. Pengurus bank harus menjaga kualitas aktiva produktifnya agar selalu dalam keadaan baik. Penilaian kualitas aktiva produktif diukur dengan menggunakan rasio Non Performing Loan (NPL), dan Penyisihan Penghapusan Aktiva Produktif (PPAP) terhadap aktiva produktif yang dimiliki bank.

Aspek ini diukur dengan menggunakan Non Performing Loan (NPL). Rasio NPL menunjukan bahwa kemampuan manajemen bank dalam mengelola kredit bermasalah yang diberikan oleh bank. Bank dalam memberikan kredit harus melakukan analisis terhadap kemampuan debitur untuk membayar kembali kewajibannya. Setelah kredit diberikan, bank wajib melakukan pemantauan terhadap penggunaan kredit serta kemampuan dan kepatuhan debitur dalam memenuhi kewajiban. Bank melakukan peninjauan, penilaian, dan peningkatan terhadap agunan untuk memperkecil risiko kredit. NPL mencerminkan risiko kredit, semakin kecil NPL, maka semakin kecil pula risiko kredit yang ditanggung pihak bank. Dengan demikian, apabila kondisi NPL suatu bank tinggi maka akan memperbesar biaya baik biaya pencadangan aktiva produktif maupun biaya lainnya sehingga berpotensi terhadap kerugian bank.

\section{Manajemen (Management)}

Penilaian kualitas manajemen suatu bank dapat dilakukan dengan menghitung rasio-rasio efisiensi usaha. Melalui rasio-rasio efisiensi usaha, tingkat efisiensi yang telah dicapai oleh manajemen bank yang bersangkutan dapat diukur secara kuantitatif. Manajemen yang dimaksud disini menunjukkan kemampuan manajemen bank untuk mengidentifikasi, mengukur, mengawasi, dan mengontrol risikorisiko yang timbul melalui kebijakan-kebijakan dan strategi bisnisnya untuk mencapai target. Manajemen suatu bank diwajibkan mengelola banknya dengan baik sesuai dengan peraturan di bidang perbankan yang berlaku agar bank tersebut sehat. 
Aspek ini diukur dengan menggunakan Net Interst Margin (NIM). Rasio NIM digunakan untuk mengukur kemampuan manajemen bank dalam mengelola aktiva produktifnya untuk menghasilkan pendapatan bunga bersih. Pendapatan bunga bersih diperoleh dari pendapatan bunga dikurangi beban bunga. Semakin besar rasio ini maka meningkatnya pendapatan bunga atas aktiva produktif yang dikelola bank sehingga kemungkinan suatu bank dalam kondisi bermasalah semakin kecil.

\section{Rentabilitas (Earnings)}

Earning merupakan kemampuan perusahaan perbankan untuk menghasilkan laba selama periode tertentu. Apabila rasio rentabilitas ini tinggi, maka hal ini menunjukkan bahwa perusahaan perbankan tersebut mampu meningkatkan usahanya melalui pencapaian laba operasi dalam periode tersebut. Perhitungan rentabilitas penting mengingat hanya bank yang memperoleh laba yang cukup yang dapat mengembangkan dirinya. Rentabilitas digunakan untuk mengukur keberhasilan manajemen menghasilkan laba melalui penanaman pada seluruh aktiva yang ada serta mengukur kemampuan bank dalam memperoleh pendapatan operasionalnya.

Aspek ini diukur dengan menggunakan Return On Assets (ROA). Analisis ROA digunakan untuk mengukur kemampuan perusahaan menghasilkan laba dengan total aset (kekayaan) yang dimiliki perusahaan setelah disesuaikan dengan biaya-biaya untuk mendanai aset tersebut. Total aset yang lazim digunakan untuk mengukur ROA sebuah bank adalah jumlah dari aset-aset produktif yang terdiri dari penempatan surat-surat berharga, penempatan dalam bentuk kredit. Semakin tinggi ROA akan semakin baik, karena untuk memperoleh ROA yang besar diperlukan adanya aktiva produktif yang berkualitas dan manajemen yang solid. Selain itu, semakin tinggi ROA, semakin besar pula kemampuan tingkat keuntungan yang dicapai bank sehingga kemungkinan suatu bank dalam kondisi bermasalah semakin kecil.

\section{Likuiditas (Liquidity)}

Likuiditas merupakan rasio yang mengukur kemampuan bank untuk memenuhi kewajiban keuangan yang harus segera dipenuhi. Kewajiban tersebut berupa call money yang harus dipenuhi pada saat adanya kliring, di mana pemenuhannya dilakukan dari aktiva lancar yang dimiliki perusahaan. Semakin besar aktiva lancar perusahaan perbankan maka semakin besar kemampuannya untuk memenuhi kewajibannya.

Aspek ini diukur dengan menggunakan Loan to Deposit Ratio (LDR). Rasio ini digunakan untuk menilai likuiditas suatu bank dengan cara membagi jumlah kredit yang diberikan oleh bank terhadap pihak ketiga. Semakin tinggi rasio ini, semakin baik tingkat kesehatan bank. Ketentuan Bank Indonesia, bahwa kategori sehat dapat dikelompokkan dalam empat kelompok yang dapat dilihat pada tabel berikut ini :

Tabel 1. Tingkat Kesehatan Bank Menurut CA
\begin{tabular}{|l|l|}
\hline Nilai Kredit CAMEL & Peringkat \\
\hline $81-100 \%$ & Sehat \\
\hline $66-81 \%$ & Cukup Sehat \\
\hline $51-66 \%$ & Kurang Sehat \\
\hline $0-51 \%$ & Tidak Sehat \\
\hline
\end{tabular}

Sumber: Kasmir, 2012

Faktor-faktor proksi rasio keuangan sesuai dengan bobotnya masing-masing dan dikuantitatifkan sesuai dengan ketentuan yang berlaku. Hasil penelitian dapat dikurangi dengan nilai kredit atas pelaksanaan ketentuan-ketentuan yang sanksinya dikaitkan dengan penilaian tingkat kesehatan bank. Berbagai ketentuan tersebut meliputi pelaksanaan pemberian Kredit Usaha Kecil (KUK), pelaksanaan pemberian kredit ekspor, pelanggaran terhadap ketentuan Batas Maksimal Pemberian Kredit (BMPK) dan pelanggaran terhadap Posisi Devisa Netto (PDN). Berdasarkan penilaian-penilaian tersebut akhirnya ditetapkan apakah bank tersebut termasuk dalam kategori sehat, cukup sehat, kurang sehat ataupun tidak 
sehat. Predikat tingkat kesehatan bank yang sehat atau cukup sehat atau kurang sehat akan diturunkan menjadi tidak sehat apabila terdapat :

1. Perselisihan intern yang diperkirakan akan menimbulkan kesulitan dalam bank yang bersangkutan.

2. Campur tangan pihak-pihak di luar bank dalam kepengurusan (manajemen) bank, termasuk di dalamnya kerjasama yang tidak wajar yang mengakibatkan salah satu atau beberapa kantornya berdiri sendiri.

3. Window dressing dalam pembukuan dan atau laporan bank secara materiil dapat berpengaruh terhadap keuangan bank sehingga mengakibatkan penilaian yang keliru terhadap bank, praktek bank dalam bank atau melakukan usaha bank di luar pembukuan bank.

4. Kesulitan keuangan yang mengakibatkan penghentian sementara atau pengunduran diri dari keikutsertaan dalam kliring.

\section{Penelitian Terdahulu}

Penelitian Clorinda (2013), yang berjudul Analisis Pengaruh Capital Ratio, Asset Quality, dan Liquidity Ratio terhadap kinerja keuangan pada sektor perbankan yang terdaftar di BEI periode 20072011, dengan menggunakan metode least square terlihat Terlihat bahwa DPK berpengaruh positif signifikan terhadap ROA. CAR dan PPAP terbukti berpengaruh negatif terhadap ROA.

Penelitian Rumondor (2013), yang berjudul Perbandingan kinerja keuangan bank Mandiri, BRI, dan BNI yang terdaftar di BEI, dengan menggunakan uji t dan uji F diperoleh ketiga bank tersebut berada pada prseidkat cukup sehat dengan peringkat komposit berada pada PK-3.

Penelitian Hutagalung,Djumahir,Ratnawati (2011) yang berjudul Analisis rasio keuangan terhadap kinerja bank umum di Indonesia, dengan metode analisis regresi berganda diperoleh hasil NPL,NIM,BOPO berpengaruh signifikan terhadap kinerja yang diproksikan dengan ROA sedangkan CAR dan LDR tidak berpengaruh signifikan terhadap kinerja yang diproksikan ROA.

Penelitian Utomo (2008) yang berjudul Pengaruh NPL terhadap kinerja keuangan berdasarkan rasio likuiditas, solvabilitas, dan profitabilitas pada Bank Mandiri dengan menggunakan analisis korelasi dan regresi berganda diperoleh hasil: ada 5 variabel yang dipengaruhi NPL: Primary ratio, Capital ratio, CAR, NPM, dan Return on equity capital, sedangakn ada 7 variabel yang tidak dipengaruhi NPL: Quick ratio, Asset to loan ratio, Cash ratio, LDR, Rate return on loan, Interest margin on earning assets, dan Interest margin on loans.

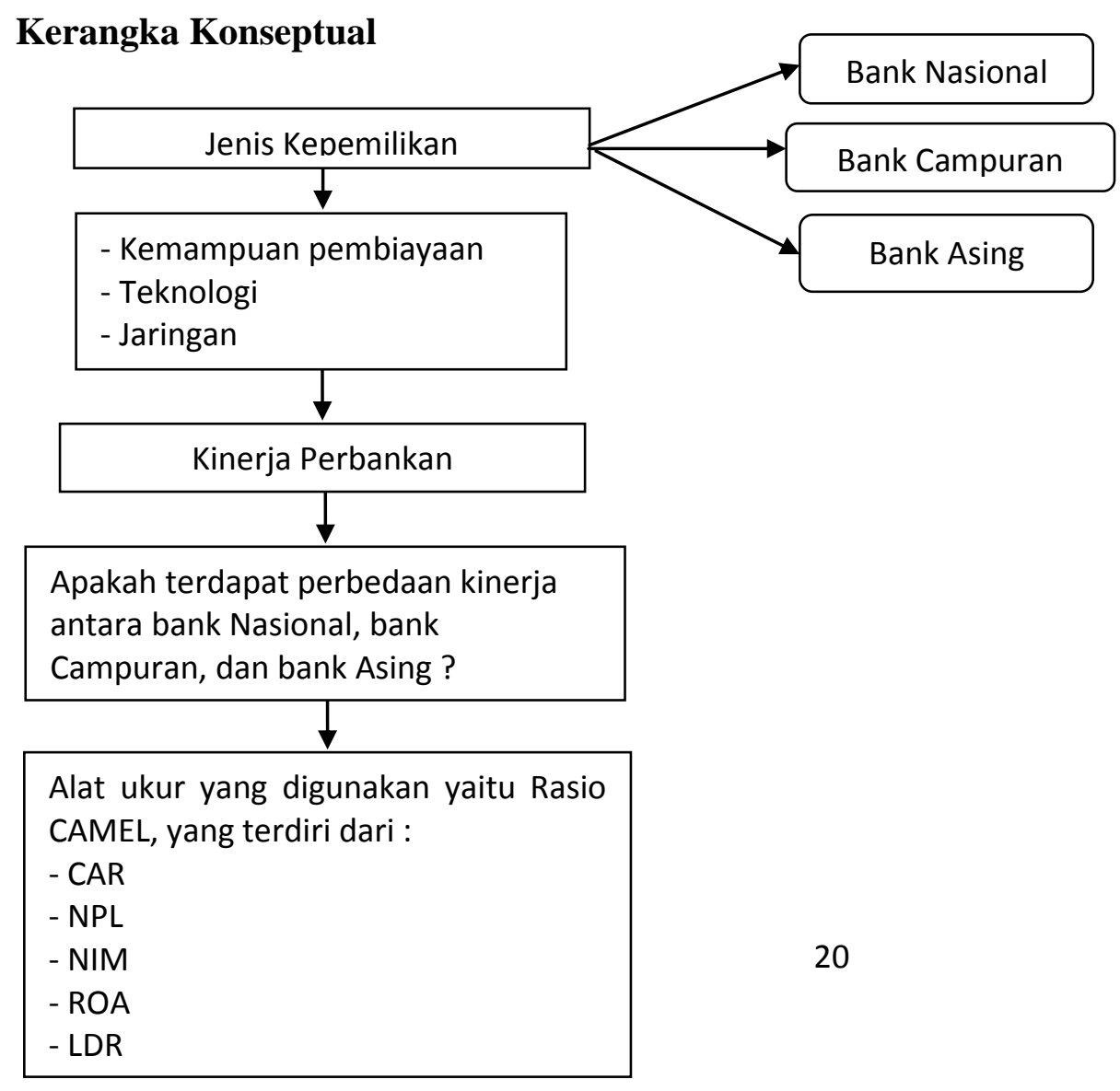




\section{Hipotesis Penelitian}

Penelitan ini menyajikan tentang analisis perbandingan kinerja pada bank nasional, bank campuran, dan bank asing yang terdaftar di Bursa Efek Indonesia (BEI) periode tahun 2004-2013. Untuk menguji apakah masing-masing proksi rasio keuangan berbeda signifikan untuk periode tahun 2004 2013, maka dirumuskan beberapa hipotesis berikut ini.

$\mathrm{H}_{1}$ : Terdapat perbedaan kinerja antara bank nasional dan bank campuran yang terdaftar di BEI periode 2004-2013.

$\mathrm{H}_{2}$ : Terdapat perbedaan kinerja antara bank nasional dan bank asing yang terdaftar di BEI periode 20042013.

$\mathrm{H}_{2}$ : Terdapat perbedaan kinerja antara bank asing dan bank campuran yang terdaftar di BEI periode 2004-2013.

\section{METODE PENELITIAN \\ Jenis Penelitian}

Jenis penelitian yang digunakan pada penelitian ini adalah explanatory (penelitian penjelasan) yakni penelitian yang menyoroti hubungan antara variabel penelitian dan pengujian hipotesis yang dirumuskan sebelumnya.

\section{Populasi dan Sampel}

Populasi dalam penelitian ini adalah seluruh bank (bank nasional dan bank asing) yang tercatat dalam Bursa Efek Indonesia (www.idx.co.id) tahun 2004-2013, yang berjumlah 42 bank. Sampel bank dipilih secara purposive sampling dengan pemilihan kriteria : merupakan perusahaan perbankan yang menerbitkan laporan keuangan sepuluh tahun berturut-turut dari tahun 2004-2013, dan laporan keuangan yang diterbitkan mempunyai tahun buku yang berakhir 31 Desember agar menghindari adanya pengaruh waktu parsial dalam perhitungan rasio keuangan. Berdasarkan kriteria tersebut maka jumlah sampel yang memenuhi kriteria adalah sebanyak 15 bank, dengan perincian : 5 bank nasional, 5 bank campuran, dan 5 bank asing.

\section{Metode Analisis}

Metode analisis yang digunakan dalam penelitian ini adalah penelitian kuantitatif dengan metode uji beda rata-rata $(t$-test). Uji t merupakan jenis pengujian statistik untuk mengetahui apakah terdapat perbedaan dari nilai yang diperkirakan dengan nilai hasil perhitungan statistik. Syarat untuk melakukan uji-t antara lain : (1) Nilai parameter diketahui/ditentukan; (2) Distribusi normal. Uji yang digunakan dalam penelitian ini adalah independent-sample t test. Independent-sample t test digunakan untuk menguji signifikansi beda rata-rata dua kelompok. Tes ini digunakan untuk menguji pengaruh variable independen terhadap variable dependen.

\section{Definisi Operasional dan Pengukuran Variabel}

Variabel yang digunakan dalam penelitian ini adalah menggunakan alat analisis metode CAMEL, yang terdiri atas:

1) Capital Adequacy Ratio / Permodalan

Capital Adequacy Ratio merupakan rasio permodalan yang menunjukkan kemampuan suatu bank dalam mengantisipasi kebutuhan akan tersedianya dana sendiri guna pertumbuhan usaha serta memikul resiko kerugian yang timbul dalam menjalankan usahanya yang diproksikan oleh CAR dan diperoleh dengan rumus :

$$
\mathrm{CAR}=\frac{\text { Modal bank }}{\text { Total ATMR }} \times 100 \%
$$

2) Asset Quality / Kualitas Aktiva Produktif

Kualitas Aktiva Produktif diproksikan dengan NPL. Rasio NPL menunjukkan bahwa kemampuan manajemen bank dalam mengelola kredit bermasalah yang diberikan oleh bank. NPL mencerminkan risiko kredit, semakin kecil NPL, maka semakin kecil pula risiko kredit yang ditanggung pihak bank. NPL diperoleh dengan rumus :

$$
\text { NPL }=\frac{\text { Kredit bermasalah }}{\text { Total Kredit }} \times 100 \%
$$


3) Management / Manajemen

Aspek manajemen diproksikan dengan Net Interest Margin (NIM). Rasio NIM digunakan untuk mengukur kemampuan manajemen bank dalam mengelola aktiva produktifnya untuk menghasilkan pendapatan bunga bersih. Pendapatan bunga bersih diperoleh dari pendapatan bunga dikurangi beban bunga. Net Interest Margin (NIM) dihitung dengan rumus:

$\mathrm{NIM}=\quad$ Pendapatan bunga bersih $\times 100 \%$

4) Earning / Rentabilitas

$$
\text { Aktiva Produktif }
$$

Aspek Earning diproksikan dengan ROA (Retun On Assets). ROA digunakan untuk mengukur kemampuan perusahaan menghasilkan laba dengan total aset (kekayaan) yang dimiliki perusahaan setelah disesuaikan dengan biaya-biaya untuk mendanai aset tersebut. Semakin tinggi ROA, semakin besar pula kemampuan tingkat keuntungan yang dicapai bank sehingga kemungkinan suatu bank dalam kondisi bermasalah semakin kecil.

$$
\mathrm{ROA}=\frac{\text { earning before taxes }}{\text { Total assets }} \times 100 \%
$$

5) Liquidity / Likuiditas

Likuiditas diproksikan dengan LDR (Loan to Deposit Ratio). LDR merupakan rasio kredit yang diberikan terhadap dana pihak ketiga, yang dimaksudkan untuk mengukur kemampuan bank dalam memenuhi pembayaran kembali deposito yang telah jatuh tempo kepada deposannya serta dapat memenuhi permohonan kredit yang diajukan tanpa terjadi penangguhan.

$\mathrm{LDR}=\frac{\text { kredit yang diberikan }}{\text { dana pihak ketiga }} \times 100 \%$

\section{HASIL PENELITIAN DAN PEMBAHASAN \\ Hasil Penelitian}

Uji Beda antara Bank Nasional dan Bank Asing

\begin{tabular}{|ll|r|r|r|r|}
\multicolumn{7}{c}{ Group Statis tics } \\
\hline & DUMMY & $\mathrm{N}$ & \multicolumn{1}{c|}{ Mean } & Std. Deviation & $\begin{array}{c}\text { Std. Error } \\
\text { Mean }\end{array}$ \\
\hline CAR & Umum & 55 & 16.2909 & 3.14273 & .42377 \\
& Asing & 50 & 29.2400 & 34.74664 & 4.91392 \\
\hline NPL & Umum & 55 & 2.1636 & 2.37864 & .32074 \\
& Asing & 50 & 1.5600 & 1.12776 & .15949 \\
\hline NIM & Umum & 55 & 6.2727 & 2.15557 & .29066 \\
& Asing & 50 & 4.7400 & 2.03851 & .28829 \\
\hline ROA & Umum & 55 & 2.6727 & 1.29178 & .17418 \\
& Asing & 50 & 2.9000 & 1.31320 & .18571 \\
\hline LDR & Umum & 55 & 70.7636 & 17.70119 & 2.38683 \\
& Asing & 50 & 75.6600 & 28.09504 & 3.97324 \\
\hline
\end{tabular}

Uraian setiap variabel adalah sebagai berikut.

1. Nilai rata-rata CAR untuk Bank Umum (Nasional) adalah 16.29 sedangkan Bank Asing memiliki nilai rata-rata sebesar 29.24. Nilai CAR yang lebih tinggi menunjukkan kemampuan bank asing menanggung resiko kerugian yang timbul lebih baik dari bank umum (nasional).

2. Nilai rata-rata NPL untuk Bank Umum (Nasional) adalah 2.16 sedangkan Bank Asing memiliki nilai rata-rata sebesar 1.56. Nilai NPL bank asing yang lebih rendah dari bank umum (nasional) menunjukkan semakin baiknya kemampuan bank asing dalam meminimalkan jumlah kredit bermasalah.

3. Nilai rata-rata NIM untuk Bank Umum (Nasional) adalah 6.27 sedangkan Bank Asing memiliki nilai rata-rata sebesar 4.74. Nilai NIM bank umum (nasional) yang lebih tinggi dari bank asing mencerminkan meningkatnya pendapatan bunga atas aktiva produktif.

4. Nilai rata-rata ROA untuk Bank Umum (Nasional) adalah 2.67 sedangkan Bank Asing memiliki nilai rata-rata sebesar 2.90. Nilai rata-rata ROA bank asing yang lebih tinggi mencerminkan peningkatan keuntungan yang dicapai, dan posisi bank yang semakin baik dari segi penggunaan aset. 
5. Nilai rata-rata LDR untuk Bank Umum (Nasional) adalah 70.76 sedangkan Bank Asing memiliki nilai rata-rata sebesar 75.66. Nilai rata-rata LDR bank asing yang lebih tinggi menunjukkan rendahnya kemampuan likuiditas bank asing sehingga kemungkinan bank dalam kondisi bermasalah yang semakin besar.

\section{Uji Beda antara Bank Nasional dan Bank Campuran}

\begin{tabular}{|ll|r|r|r|r|}
\multicolumn{7}{c}{ Group Statistics } \\
\hline \multirow{2}{*}{ DUMMY } & $\mathrm{N}$ & Mean & Std. Deviation & $\begin{array}{c}\text { Std. Error } \\
\text { Mean }\end{array}$ \\
\hline CAR & Umum & 55 & 16.2909 & 3.14273 & .42377 \\
& Campuran & 50 & 22.6400 & 16.75972 & 2.37018 \\
\hline NPL & Umum & 55 & 2.1636 & 2.37864 & .32074 \\
& Campuran & 50 & 1.4400 & .73290 & .10365 \\
\hline NIM & Umum & 55 & 6.2727 & 2.15557 & .29066 \\
& Campuran & 50 & 5.5000 & 3.05894 & .43260 \\
\hline ROA & Umum & 55 & 2.6727 & 1.29178 & .17418 \\
& Campuran & 50 & 1.9800 & 2.50298 & .35397 \\
\hline LDR & Umum & 55 & 70.7636 & 17.70119 & 2.38683 \\
& Campuran & 50 & 74.6600 & 28.29842 & 4.00200 \\
\hline
\end{tabular}

Uraian setiap variabel adalah sebagai berikut.

1. Nilai rata-rata CAR untuk Bank Umum (Nasional) adalah 16.29 sedangkan Bank Campuran memiliki nilai rata-rata sebesar 22.64. Nilai CAR yang lebih tinggi menunjukkan kemampuan bank campuran menanggung resiko kerugian yang timbul lebih baik dari bank umum (nasional).

2. Nilai rata-rata NPL untuk Bank Umum (Nasional) adalah 2.16 sedangkan Bank Campuran memiliki nilai rata-rata sebesar 1.44. Nilai NPL bank campuran yang lebih rendah dari bank umum (nasional) menunjukkan semakin baiknya kemampuan bank campuran dalam meminimalkan jumlah kredit bermasalah.

3. Nilai rata-rata NIM untuk Bank Umum (Nasional) adalah 6.27 sedangkan Bank Campuran memiliki nilai rata-rata sebesar 5.50. Nilai NIM bank umum (nasional) yang lebih tinggi dari bank campuran mencerminkan meningkatnya pendapatan bunga atas aktiva produktif.

4. Nilai rata-rata ROA untuk Bank Umum (Nasional) adalah 2.67 sedangkan Bank Campuran memiliki nilai rata-rata sebesar 1.98. Nilai rata-rata ROA bank campuran yang lebih tinggi mencerminkan peningkatan keuntungan yang dicapai, dan posisi bank yang semakin baik dari segi penggunaan aset.

5. Nilai rata-rata LDR untuk Bank Umum (Nasional) adalah 70.76 sedangkan Bank Campuran memiliki nilai rata-rata sebesar 74.66. Nilai rata-rata LDR bank campuran yang lebih tinggi menunjukkan rendahnya kemampuan likuiditas bank campuran sehingga kemungkinan bank dalam kondisi bermasalah yang semakin besar.

\section{Uji Beda antara Bank Asing dan Bank Campuran}

Group Statistics

\begin{tabular}{|ll|r|r|r|r|}
\hline & DUMMY & $\mathrm{N}$ & \multicolumn{1}{c|}{ Mean } & Std. Deviation & $\begin{array}{c}\text { Std. Error } \\
\text { Mean }\end{array}$ \\
\hline CAR & Asing & 50 & 29.2400 & 34.74664 & 4.91392 \\
& Campuran & 50 & 22.6400 & 16.75972 & 2.37018 \\
\hline NPL & Asing & 50 & 1.5600 & 1.12776 & .15949 \\
& Campuran & 50 & 1.4400 & .73290 & .10365 \\
\hline NIM & Asing & 50 & 4.7400 & 2.03851 & .28829 \\
& Campuran & 50 & 5.5000 & 3.05894 & .43260 \\
\hline ROA & Asing & 50 & 2.9000 & 1.31320 & .18571 \\
& Campuran & 50 & 1.9800 & 2.50298 & .35397 \\
\hline LDR & Asing & 50 & 75.6600 & 28.09504 & 3.97324 \\
& Campuran & 50 & 74.6600 & 28.29842 & 4.00200 \\
\hline
\end{tabular}


Uraian setiap variabel adalah sebagai berikut.

1. Nilai rata-rata CAR untuk Bank Asing adalah 29.24 sedangkan Bank Campuran memiliki nilai rata-rata sebesar 22.64. Nilai CAR yang lebih tinggi menunjukkan kemampuan bank asing menanggung resiko kerugian yang timbul lebih baik dari bank campuran.

2. Nilai rata-rata NPL untuk Bank Asing adalah 1.56 sedangkan Bank Campuran memiliki nilai rata-rata sebesar 1.44. Nilai NPL bank campuran yang lebih rendah dari bank asing menunjukkan semakin baiknya kemampuan bank campuran dalam meminimalkan jumlah kredit bermasalah.

3. Nilai rata-rata NIM untuk Bank Asing adalah 4.74 sedangkan Bank Campuran memiliki nilai rata-rata sebesar 5.50. Nilai NIM bank campuran yang lebih tinggi dari bank campuran mencerminkan meningkatnya pendapatan bunga atas aktiva produktif.

4. Nilai rata-rata ROA untuk Bank Asing adalah 2.90 sedangkan Bank Campuran memiliki nilai rata-rata sebesar 1.98. Nilai rata-rata ROA bank asing yang lebih tinggi mencerminkan peningkatan keuntungan yang dicapai, dan posisi bank yang semakin baik dari segi penggunaan aset.

5. Nilai rata-rata LDR untuk Bank Asing adalah 75.66 sedangkan Bank Campuran memiliki nilai rata-rata sebesar 74.66. Nilai rata-rata LDR bank asing yang lebih tinggi dari bank campuran menunjukkan kemungkinan bank dalam kondisi bermasalah yang semakin besar.

\section{Pembahasan}

\section{Pengujian Hipotesis 1.}

Hipotesis $1\left(\mathrm{H}_{1}\right)$ menyatakan terdapat perbedaan kinerja keuangan antara bank umum (nasional) dan bank asing yang terdaftar di BEI periode 2004-2013. Berdasarkan hasil pengujian dengan menggunakan uji beda rata-rata, maka hasil pengujian untuk perbandingan kinerja pada bank asing dengan bank umum (nasional) dapat dilihat pada Tabel 5.7.

\section{Uji Beda Rata-rata Bank Umum (Nasional) dan Bank Asing}

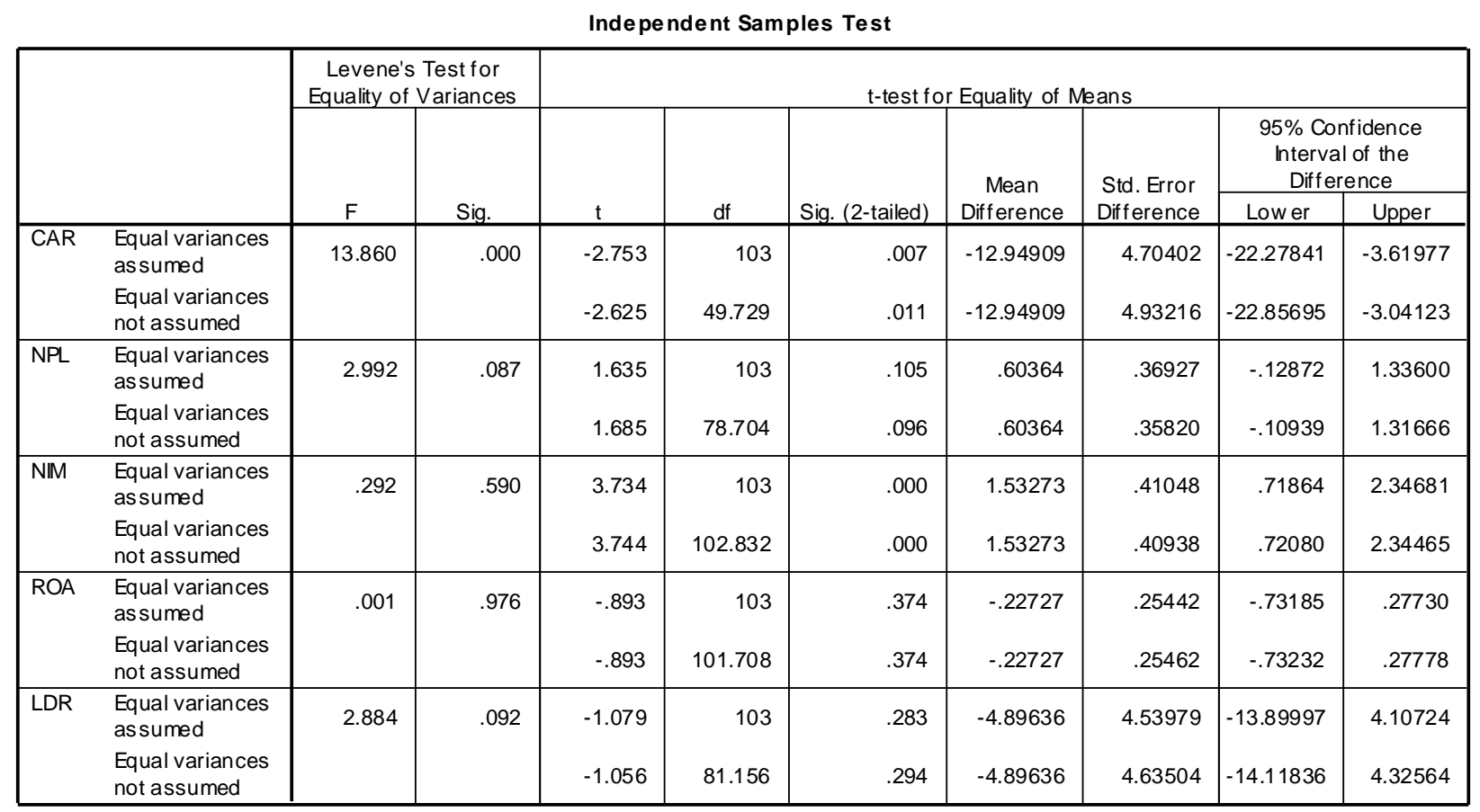

Sumber : Data olahan (2014)

Nilai CAR bank umum (nasional) adalah 16.29 sedangkan nilai CAR bank asing adalah 29.24, sehingga hal ini menunjukkan bahwa CAR bank asing masih lebih tinggi. Uji Levene menunjukkan nilai F sebesar 13.860 dengan signifikansi 0.000 yang menunjukkan bahwa variansi data tidak sama (equal variances not assumed), sehingga hasil perbedaan antara CAR bank umum (nasional) dan bank asing 
adalah signifikan berbeda karena terdapat perbedaan yang cukup mencolok sebesar 12.95, namun masih tergolong dalam kriteria yang sehat (hasil rasio $\geq 8 \%$ ). Dengan demikian rasio CAR bank asing yang lebih tinggi dari bank nasional menunjukkan semakin baiknya kinerja dan kemampuan bank asing dalam menanggung resiko dari setiap kredit/aktiva produktif yang beresiko. Disamping itu, bank asing juga memiliki kemampuan lebih baik dalam membiayai kegiatan operasionalnya dan memberikan kontribusi yang cukup besar bagi profitabilitas bank tersebut.

Nilai NPL bank umum (nasional) adalah 2.16 sedangkan nilai NPL bank asing adalah 1.56, yang menunjukkan bahwa NPL bank asing masih lebih rendah. Uji Levene menunjukkan nilai F sebesar 2.992 dengan signifikansi 0.087 yang memiliki bahwa variansi data adalah sama (equal variances assumed). Hasil perbedaan antara NPL bank umum (nasional) dan bank asing adalah tidak signifikan berbeda, karena perbedaan yang tidak signifikan $\leq 1$. Dengan demikian rasio NPL bank asing yang lebih rendah dari bank nasional menunjukkan tingkat kemampuan bank asing yang semakin baik dalam mengelola jumlah kredit bermasalah, semakin tingginya standarisasi analisis dalam pemilihan calon debitur, dan pengawasan yang semakin baik dibandingkan dengan bank nasional, namun keduanya termasuk dalam kriteria yang tidak sehat (hasil rasio $\leq 6 \%$ ).

Nilai NIM bank umum (nasional) adalah 6.27 sedangkan nilai NIM bank asing adalah 4.74, hal ini menunjukkan bahwa NIM bank asing masih lebih rendah. Uji Levene menunjukkan nilai F sebesar 0.292 dengan signifikansi 0.590 yang memiliki bahwa variansi data adalah sama (equal variances assumed), sehingga hasil perbedaan antara NIM bank umum (nasional) dan bank asing adalah signifikan berbeda, karena terdapat perbedaan sebesar 1.53 (tingkat signifikansi >1), namun masih tergolong dalam kriteria yang sehat (hasil rasio $\geq 1.5 \%$ ). Rasio NIM bank nasional yang lebih tinggi dari bank asing menunjukkan semakin baiknya tingkat kemampuan bank nasional dalam menghasilkan pendapatan dari bunga dengan melihat kinerja bank dalam menyalurkan kredit. Mengingat pendapatan operasional bank sangat tergantung dari selisih bunga (spread) dari kredit yang disalurkan.

Nilai ROA bank umum (nasional) adalah 2.67 sedangkan nilai ROA bank asing adalah 2.90, sehingga hal ini menunjukkan bahwa ROA bank asing masih lebih tinggi. Uji Levene menunjukkan nilai F sebesar 0.001 dengan signifikansi 0.976 yang memiliki bahwa variansi data adalah sama (equal variances assumed), sehingga memiliki hasil perbedaan antara ROA bank umum (nasional) dan bank asing adalah tidak signifikan berbeda, karena perbedaan yang tidak signifikan $\leq 1$ namun masih tergolong dalam kriteria yang sehat (hasil rasio $\geq 0.5 \%$ ). Nilai ROA bank asing yang lebih tinggi menunjukkan kinerja bank yang semakin baik pula, karena tingkat pengembalian investasi semakin besar, disamping itu, menunjukkan pengaruh gabungan dari likuiditas, manajemen aktiva, dan utang terhadap hasil operasi.

Nilai LDR bank umum (nasional) adalah 70.76 sedangkan nilai LDR bank asing adalah 75.66, sehingga hal ini menunjukkan bahwa LDR bank asing masih lebih tinggi. Uji Levene menunjukkan nilai F sebesar 2.884 dengan signifikansi 0.092 yang memiliki bahwa variansi data adalah sama (equal variances assumed), sehingga memiliki hasil perbedaan antara LDR bank umum (nasional) dan bank asing adalah tidak signifikan berbeda karena masih tergolong dalam kriteria yang sehat (hasil rasio 50\%$\leq 100 \%$ ). Rasio LDR bank asing yang lebih tinggi memberikan indikasi semakin rendahnya kemampuan likuiditas yang berdampak pada kinerja bank asing. Hal ini disebabkan karena jumlah dana yang diperlukan untuk membiayai kredit menjadi semakin besar.

\section{Pengujian Hipotesis 2.}

Hipotesis $2\left(\mathrm{H}_{2}\right)$ menyatakan terdapat perbedaan kinerja keuangan antara bank umum (nasional) dan bank campuran yang terdaftar di BEI periode tahun 2004-2013. Berdasarkan hasil pengujian dengan menggunakan uji beda rata-rata, diketahui nilai perbandingan kinerja pada bank umum (nasional) dengan bank campuran. Nilai CAR bank umum (nasional) adalah 16.29 sedangkan nilai CAR bank campuran adalah 22.64, sehingga hal ini menunjukkan bahwa CAR bank campuran masih lebih tinggi. Uji Levene menunjukkan nilai $\mathrm{F}$ sebesar 27.288 dengan signifikansi 0.000 yang memiliki bahwa variansi data tidak sama (equal variances not assumed), sehingga memiliki hasil perbedaan antara CAR bank umum (nasional) dan bank campuran adalah signifikan berbeda karena terdapat perbedaan yang cukup mencolok sebesar 6.35, namun masih tergolong dalam kriteria yang sehat (hasil rasio $\geq 8 \%$ ). Rasio CAR bank campuran yang lebih tinggi menunjukkan semakin baiknya kemampuan bank campuran dalam menanggung resiko dari setiap kredit/aktiva produktif yang beresiko. Disamping itu, bank campuran juga 
memiliki kemampuan lebih baik dalam membiayai kegiatan operasionalnya dan memberikan kontribusi yang cukup besar bagi profitabilitas bank tersebut.

\section{Uji Beda Rata-rata Bank Umum (Nasional) dan Bank Campuran}

\begin{tabular}{|c|c|c|c|c|c|c|c|c|c|c|}
\hline \multicolumn{11}{|c|}{ Independent Samples Test } \\
\hline & & \multicolumn{2}{|c|}{$\begin{array}{l}\text { Levene's Test for } \\
\text { Equality of } V \text { ariances }\end{array}$} & \multicolumn{7}{|c|}{ t-test for Equality of Means } \\
\hline & & \multirow[b]{2}{*}{$\mathrm{F}$} & \multirow[b]{2}{*}{ Sig. } & \multirow[b]{2}{*}{$t$} & \multirow[b]{2}{*}{ df } & \multirow[b]{2}{*}{ Sig. (2-tailed) } & \multirow{2}{*}{$\begin{array}{c}\text { Mean } \\
\text { Difference }\end{array}$} & \multirow{2}{*}{$\begin{array}{l}\text { Std. Error } \\
\text { Difference }\end{array}$} & \multicolumn{2}{|c|}{$\begin{array}{l}95 \% \text { Confidence } \\
\text { Interval of the } \\
\text { Difference }\end{array}$} \\
\hline & & & & & & & & & Low er & Upper \\
\hline \multirow[t]{2}{*}{ CAR } & $\begin{array}{l}\text { Equal variances } \\
\text { assumed }\end{array}$ & 27.288 & .000 & -2.758 & 103 & .007 & -6.34909 & 2.30213 & -10.91483 & -1.78336 \\
\hline & $\begin{array}{l}\text { Equal variances } \\
\text { not assumed }\end{array}$ & & & -2.637 & 52.134 & .011 & -6.34909 & 2.40777 & -11.18033 & -1.51785 \\
\hline \multirow[t]{2}{*}{ NPL } & $\begin{array}{l}\text { Equal variances } \\
\text { assumed }\end{array}$ & 5.719 & .019 & 2.063 & 103 & .042 & .72364 & .35073 & .02804 & 1.41924 \\
\hline & $\begin{array}{l}\text { Equal variances } \\
\text { not assumed }\end{array}$ & & & 2.147 & 65.085 & .036 & .72364 & .33707 & .05048 & 1.39679 \\
\hline \multirow[t]{2}{*}{ NIM } & $\begin{array}{l}\text { Equal variances } \\
\text { assumed }\end{array}$ & 2.144 & .146 & 1.507 & 103 & .135 & .77273 & .51281 & -.24431 & 1.78977 \\
\hline & $\begin{array}{l}\text { Equal variances } \\
\text { not assumed }\end{array}$ & & & 1.483 & 87.116 & .142 & .77273 & .52118 & -.26315 & 1.80860 \\
\hline \multirow[t]{2}{*}{ ROA } & $\begin{array}{l}\text { Equal variances } \\
\text { assumed }\end{array}$ & .750 & .388 & 1.806 & 103 & .074 & .69273 & .38367 & -.06818 & 1.45364 \\
\hline & $\begin{array}{l}\text { Equal variances } \\
\text { not assumed }\end{array}$ & & & 1.756 & 71.784 & .083 & .69273 & .39451 & -.09375 & 1.47921 \\
\hline \multirow[t]{2}{*}{ LDR } & $\begin{array}{l}\text { Equal variances } \\
\text { assumed }\end{array}$ & 4.208 & .043 & -.854 & 103 & .395 & -3.89636 & 4.56268 & -12.94536 & 5.15263 \\
\hline & $\begin{array}{l}\text { Equal variances } \\
\text { not assumed }\end{array}$ & & & -.836 & 80.784 & .406 & -3.89636 & 4.65972 & -13.16811 & 5.37539 \\
\hline
\end{tabular}

Sumber : Data olahan (2014)

Nilai NPL bank umum (nasional) adalah 2.16 sedangkan nilai NPL bank campuran adalah 1.44, sehingga hal ini menunjukkan bahwa NPL bank campuran masih lebih rendah. Uji Levene menunjukkan nilai $\mathrm{F}$ sebesar 5.719 dengan signifikansi 0.019 yang memiliki bahwa variansi data adalah tidak sama (equal variances not assumed), sehingga memiliki hasil perbedaan antara NPL bank umum (nasional) dan bank campuran adalah signifikan berbeda. Rasio NPL bank campuran yang lebih rendah menunjukkan tingkat kemampuan bank campuran yang semakin baik dalam mengelola jumlah kredit bermasalah, semakin tingginya standarisasi analisis dalam pemilihan calon debitur, dan pengawasan yang semakin baik dibandingkan dengan bank nasional namun keduanya termasuk dalam kriteria yang tidak sehat (hasil rasio $\leq 6 \%$ ).

Nilai NIM bank umum (nasional) adalah 6.27 sedangkan nilai NIM bank campuran adalah 5.50, sehingga hal ini menunjukkan bahwa NIM bank campuran masih lebih rendah. Uji Levene menunjukkan nilai $\mathrm{F}$ sebesar 2.144 dengan signifikansi 0.146 yang memiliki bahwa variansi data adalah sama (equal variances assumed), sehingga memiliki hasil perbedaan antara NIM bank umum (nasional) dan bank campuran adalah tidak signifikan berbeda, karena perbedaan yang tidak signifikan $\leq 1$ namun masih tergolong dalam kriteria yang sehat (hasil rasio $\geq 1.5 \%$ ). Rasio NIM bank nasional yang lebih tinggi menunjukkan semakin baiknya tingkat kemampuan bank nasional dalam menghasilkan pendapatan dari bunga dengan melihat kinerja bank dalam menyalurkan kredit. Mengingat pendapatan operasional bank sangat tergantung dari selisih bunga (spread) dari kredit yang disalurkan.

Nilai ROA bank umum (nasional) adalah 2.67 sedangkan nilai ROA bank campuran adalah 1.98, sehingga hal ini menunjukkan bahwa ROA bank campuran masih lebih tinggi. Uji Levene menunjukkan nilai $\mathrm{F}$ sebesar 0.750 dengan signifikansi 0.388 yang memiliki bahwa variansi data adalah sama (equal variances assumed), sehingga memiliki hasil perbedaan antara ROA bank umum (nasional) dan bank campuran adalah tidak signifikan berbeda, karena perbedaan yang tidak signifikan $\leq 1$ namun masih tergolong dalam kriteria yang sehat (hasil rasio $\geq 0.5 \%$ ). Nilai ROA bank nasional yang lebih tinggi menunjukkan kinerja bank yang semakin baik pula, dibanding dengan bank campuran karena tingkat pengembalian investasi semakin besar, disamping itu, menunjukkan pengaruh gabungan dari likuiditas, manajemen aktiva, dan utang terhadap hasil operasi.

Nilai LDR bank umum (nasional) adalah 70.76 sedangkan nilai LDR bank campuran adalah 74.66, sehingga hal ini menunjukkan bahwa LDR bank campuran masih lebih tinggi. Uji Levene menunjukkan nilai $\mathrm{F}$ sebesar 4.208 dengan signifikansi 0.043 yang memiliki bahwa variansi data adalah tidak sama (equal variances not assumed), sehingga memiliki hasil perbedaan antara LDR bank umum (nasional) dan bank campuran adalah tidak signifikan berbeda karena masih tergolong dalam kriteria yang sehat (hasil rasio 50\%- $\leq 100 \%$ ). Rasio LDR bank campuran yang lebih tinggi memberikan indikasi 
semakin rendahnya kemampuan likuiditasnya. Hal ini disebabkan karena jumlah dana yang diperlukan untuk membiayai kredit menjadi semakin besar, karena Loan To Deposit Ratio (LDR) merupakan rasio antara besarnya seluruh volume kredit yang disalurkan oleh bank dan jumlah penerimaan dana dari berbagai sumber.

\section{Pengujian Hipotesis 3.}

Hipotesis $3\left(\mathrm{H}_{3}\right)$ menyatakan terdapat perbedaan kinerja keuangan antara bank asing dan bank campuran yang terdaftar di BEI periode tahun 2004-2013. Berdasarkan hasil pengujian dengan menggunakan uji beda rata-rata, hasil pengujiannya dapat dilihat pada tabel berikut.

\section{Uji Beda Rata-rata Bank Asing dan Bank Campuran}

\begin{tabular}{|c|c|c|c|c|c|c|c|c|c|c|}
\hline \multicolumn{11}{|c|}{ Independent Samples Test } \\
\hline & & \multicolumn{2}{|c|}{$\begin{array}{l}\text { Levene's Test for } \\
\text { Equality of Variances }\end{array}$} & \multicolumn{7}{|c|}{$\mathrm{t}$-test for Equality of Means } \\
\hline & & \multirow[b]{2}{*}{$\mathrm{F}$} & \multirow[b]{2}{*}{ Sig. } & \multirow[b]{2}{*}{$t$} & \multirow[b]{2}{*}{ df } & \multirow[b]{2}{*}{ Sig. (2-tailed) } & \multirow{2}{*}{$\begin{array}{c}\text { Mean } \\
\text { Difference }\end{array}$} & \multirow{2}{*}{$\begin{array}{l}\text { Std. Error } \\
\text { Difference }\end{array}$} & \multicolumn{2}{|c|}{$\begin{array}{l}95 \% \text { Confidence } \\
\text { Interval of the } \\
\text { Difference }\end{array}$} \\
\hline & & & & & & & & & Lower & Upper \\
\hline CAR & $\begin{array}{l}\text { Equal variances } \\
\text { assumed } \\
\text { Equal variances } \\
\text { not assumed }\end{array}$ & 1.845 & .178 & $\begin{array}{l}1.210 \\
1.210\end{array}$ & $\begin{array}{r}98 \\
70.629\end{array}$ & $\begin{array}{l}.229 \\
.230\end{array}$ & $\begin{array}{l}6.60000 \\
6.60000\end{array}$ & $\begin{array}{l}5.45567 \\
5.45567\end{array}$ & $\begin{array}{l}-4.22660 \\
-4.27929\end{array}$ & $\begin{array}{r}17.42660 \\
17.47929\end{array}$ \\
\hline NPL & $\begin{array}{l}\text { Equal variances } \\
\text { assumed } \\
\text { Equal variances } \\
\text { not assumed }\end{array}$ & 1.564 & .214 & $\begin{array}{l}.631 \\
.631\end{array}$ & $\begin{array}{r}98 \\
84.124\end{array}$ & $\begin{array}{l}.530 \\
.530\end{array}$ & $\begin{array}{l}.12000 \\
.12000\end{array}$ & $\begin{array}{l}.19021 \\
.19021\end{array}$ & $\begin{array}{l}-.25746 \\
-.25824\end{array}$ & $\begin{array}{l}.49746 \\
.49824\end{array}$ \\
\hline NIM & $\begin{array}{l}\text { Equal variances } \\
\text { assumed } \\
\text { Equal variances } \\
\text { not assumed }\end{array}$ & 3.279 & .073 & $\begin{array}{l}-1.462 \\
-1.462\end{array}$ & $\begin{array}{r}98 \\
85.352\end{array}$ & $\begin{array}{l}.147 \\
.147\end{array}$ & $\begin{array}{l}-.76000 \\
-.76000\end{array}$ & $\begin{array}{l}.51986 \\
.51986\end{array}$ & $\begin{array}{l}-1.79164 \\
-1.79356\end{array}$ & $\begin{array}{l}.27164 \\
.27356\end{array}$ \\
\hline ROA & $\begin{array}{l}\text { Equal variances } \\
\text { assumed } \\
\text { Equal variances } \\
\text { not assumed }\end{array}$ & .660 & .419 & $\begin{array}{l}2.302 \\
2.302\end{array}$ & $\begin{array}{r}98 \\
74.076\end{array}$ & $\begin{array}{l}.023 \\
.024\end{array}$ & $\begin{array}{l}.92000 \\
.92000\end{array}$ & $\begin{array}{l}.39973 \\
.39973\end{array}$ & $\begin{array}{l}.12674 \\
.12352\end{array}$ & $\begin{array}{l}1.71326 \\
1.71648\end{array}$ \\
\hline LDR & $\begin{array}{l}\text { Equal variances } \\
\text { as sumed } \\
\text { Equal variances } \\
\text { not assumed }\end{array}$ & .055 & .814 & $\begin{array}{l}.177 \\
.177\end{array}$ & $\begin{array}{r}98 \\
97.995\end{array}$ & $\begin{array}{l}.860 \\
.860\end{array}$ & $\begin{array}{l}1.00000 \\
1.00000\end{array}$ & $\begin{array}{l}5.63938 \\
5.63938\end{array}$ & $\begin{array}{l}-10.19117 \\
-10.19118\end{array}$ & $\begin{array}{r}12.19117 \\
12.19118\end{array}$ \\
\hline
\end{tabular}

Sumber : Data olahan (2014)

Nilai CAR bank asing adalah 29.24 sedangkan nilai CAR bank campuran adalah 22.64, sehingga hal ini menunjukkan bahwa CAR bank asing masih lebih tinggi. Uji Levene menunjukkan nilai F sebesar 1.845 dengan signifikansi 0.178 yang memiliki bahwa variansi data adalah sama (equal variances assumed), sehingga memiliki hasil perbedaan antara CAR bank asing dan bank campuran adalah tidak signifikan berbeda karena masih tergolong dalam range kriteria yang sehat (hasil rasio $\geq 8 \%$ ) Rasio CAR bank asing yang lebih tinggi dari bank campuran menunjukkan semakin baiknya kemampuan bank asing dalam menanggung resiko dari setiap kredit/aktiva produktif yang beresiko. Disamping itu juga memiliki kemampuan lebih baik dalam membiayai kegiatan operasionalnya dan memberikan kontribusi yang cukup besar bagi profitabilitas bank tersebut.

Nilai NPL bank asing adalah 1.56 sedangkan nilai NPL bank campuran adalah 1.44, sehingga hal ini menunjukkan bahwa NPL bank campuran masih lebih rendah. Uji Levene menunjukkan nilai $\mathrm{F}$ sebesar 1.564 dengan signifikansi 0.214 yang memiliki bahwa variansi data adalah sama (equal variances assumed), sehingga memiliki hasil perbedaan antara NPL bank asing dan bank campuran adalah tidak signifikan berbeda karena perbedaan yang tidak signifikan $\leq 1$. Rasio NPL bank campuran yang lebih rendah dari bank asing menunjukkan tingkat kemampuan bank campuran yang semakin baik dalam mengelola jumlah kredit bermasalah, semakin tingginya standarisasi analisis dalam pemilihan calon debitur, dan pengawasan yang semakin baik dibandingkan dengan bank asing, namun keduanya termasuk dalam kriteria yang tidak sehat (hasil rasio $\leq 6 \%$ ).

Nilai NIM bank asing adalah 4.74 sedangkan nilai NIM bank campuran adalah 5.50, sehingga hal ini menunjukkan bahwa NIM bank campuran masih lebih tinggi. Uji Levene menunjukkan nilai F sebesar 3.279 dengan signifikansi 0.073 yang memiliki bahwa variansi data adalah sama (equal variances assumed), sehingga memiliki hasil perbedaan antara NIM bank asing dan bank campuran adalah tidak signifikan berbeda, karena perbedaan yang tidak signifikan $\leq 1$ namun masih tergolong dalam kriteria yang sehat (hasil rasio $\geq 1.5 \%$ ). Rasio NIM bank campuran yang lebih tinggi dari bank asing 
menunjukkan semakin baiknya tingkat kemampuan bank campuran dalam menghasilkan pendapatan dari bunga dengan melihat kinerja bank dalam menyalurkan kredit. Mengingat pendapatan operasional bank sangat tergantung dari selisih bunga (spread) dari kredit yang disalurkan.

Nilai ROA bank asing adalah 2.90 sedangkan nilai ROA bank campuran adalah 1.98, sehingga hal ini menunjukkan bahwa ROA bank asing masih lebih tinggi. Uji Levene menunjukkan nilai $F$ sebesar 0.660 dengan signifikansi 0.419 yang memiliki bahwa variansi data adalah sama (equal variances assumed), sehingga memiliki hasil perbedaan antara ROA bank asing dan bank campuran adalah signifikan berbeda. karena masih tergolong dalam range kriteria yang sehat (hasil rasio $\geq 0.5 \%$ ). Nilai ROA bank asing yang lebih tinggi menunjukkan kinerja bank yang semakin baik pula, dibanding dengan bank campuran karena tingkat pengembalian investasi semakin besar, disamping itu, menunjukkan pengaruh gabungan dari likuiditas, manajemen aktiva, dan utang terhadap hasil operasi.

Nilai LDR bank asing adalah 75.66 sedangkan nilai LDR bank campuran adalah 74.66, sehingga hal ini menunjukkan bahwa LDR bank asing masih lebih tinggi. Uji Levene menunjukkan nilai $\mathrm{F}$ sebesar 0.055 dengan signifikansi 0.814 yang memiliki bahwa variansi data adalah sama (equal variances assumed), sehingga memiliki hasil perbedaan antara LDR bank asing dan bank campuran adalah tidak signifikan berbeda karena masih tergolong dalam rentang kriteria yang sehat (hasil rasio 50\%- $\leq 100 \%$ ). Rasio LDR bank asing yang lebih tinggi memberikan indikasi semakin rendahnya kemampuan likuiditasnya. Hal ini disebabkan karena jumlah dana yang diperlukan untuk membiayai kredit menjadi semakin besar, karena Loan To Deposit Ratio (LDR) merupakan rasio antara besarnya seluruh volume kredit yang disalurkan oleh bank dan jumlah penerimaan dana dari berbagai sumber. Hasil rasio-rasio keuangan dari bank asing yang lebih baik dari bank nasional disebabkan oleh karena adanya hasil pengelolaan manajerial yang lebih baik dari segi permodalan, kualitas aktiva produktif, manajemen, rentabilitas, dan likuiditas yang diproksikan dengan CAMEL.

Penelitian ini mendukung hasil penelitian sebelumnya oleh Rumondor (2013) yang menyimpulkan bahwa rasio CAMEL mempunyai pengaruh yang signifikan terhadap kinerja keuangan perbankan.

\section{PENUTUP}

\section{Kesimpulan}

Bedasarkan hasil penelitian dan pembahasan pada bab sebelumnya, maka disampaikan beberapa kesimpulan sebagai berikut.

1. Perbandingan rasio CAMEL antara bank nasional dan bank asing yang menunjukkan; dilihat rasio CAR, NPL, dan ROA bank asing lebih unggul dibandingkan bank nasional. Namun dilihat dari rasio NIM dan LDR bank nasional lebih unggul dari bank asing. Secara keseluruhan kinerja bank asing lebih unggul dibandingkan dengan kinerja bank nasional.

2. Perbandingan rasio CAMEL antara bank nasional dan bank campuran yang menunjukkan; dilihat rasio NIM, ROA, dan LDR bank nasional lebih unggul dibandingkan bank campuran. Namun dilihat dari rasio CAR dan NPL bank campuran lebih unggul dari bank nasional. Secara keseluruhan kinerja bank nasional lebih unggul dibandingkan dengan kinerja bank campuran.

3. Perbandingan rasio CAMEL antara bank asing dan bank campuran yang menunjukkan; dilihat rasio NPL, NIM, dan LDR bank campuran lebih unggul dibandingkan bank asing. Namun dilihat dari rasio CAR dan ROA bank asing lebih unggul dari bank campuran. Secara keseluruhan kinerja bank campuran lebih unggul dibandingkan dengan kinerja bank asing.

Berdasarkan penentuan tingkat kesehatan bank menurut CAMEL dan hasil pengujian perbandingan nilai rata-rata kinerja, bank campuran lebih unggul dibandingkan dengan kinerja bank asing, dan bank asing lebih unggul dibandingkan dengan kinerja bank nasional. Sehingga bank nasional memiliki kinerja yang terendah dibandingkan dengan kinerja bank campuran dan bank asing. Perbedaan signifikan antara kinerja bank nasional dan bank asing terletak pada rasio CAR dan NIM, bank nasional dan bank campuran terletak pada rasio NPL, bank asing dan bank campuran terletak pada rasio ROA.

\section{Saran}

Berdasarkan hasil pengujian ditemukan bahwa rasio-rasio CAMEL pada bank nasional masih belum terlalu baik dibandingkan dengan rasio-rasio yang dimiliki oleh bank asing dan bank campuran. Sehingga 
disarankan kepada pihak manajemen bank nasional untuk lebih memperhatikan pengelolaan yang ada pada organisasinya dari segi permodalan, kualitas aset, manajemen, rentabilitas, dan likuiditas untuk memaksimalkan kinerjanya sehingga rasio ROA bisa lebih meningkat, karena ROA merupakan salah satu indikator yang digunakan untuk mengukur tingkat keuntungan yang dicapai, dan digunakan investor dalam pengambilan keputusan berinvestasi.

Lebih lanjut, diharapkan penelitian ini dapat menjadi referensi bagi penelitian selanjutnya yang berada di bidang yang sama, serta dapat dikembangkan lebih lanjut model penelitiannya agar dapat memberikan kontribusi yang lebih mendalam atas peningkatan kinerja manajerial khususnya yang berada di pihak Bank Nasional.

\section{DAFTAR PUSTAKA}

Amalia, Alia. 2010. Pengaruh CAR, NPL, NIM, BOPO, LDR, dan PPAP Terhadap Kinerja Rentabilitas Bank (Studi Kasus Pada Bank Devisa dan Bank Non Devisa Tahun 2004-2008). Skripsi Fakultas Ekonomi. Universitas Diponegoro. Semarang.

Bank Indonesia. Laporan Keuangan Publikasi Bank. www.bi.go.id diakses Mei 08 2014. Manado.

Clorinda, Karunia. 2013. Analisis Pengaruh Rasio Capital, Asset Quality, dan Liquidity Terhadap Kinerja Keuangan Pada Sektor Perbankan Yang Terdaftar di Bursa Efek Indonesia Periode 20072011. Jurnal Ilmiah. Universitas Surabaya. Surabaya.

Djiwandono, J, Soedrajad. 2002. Masalah Burden Sharing Pembiayaan BLBI antara pemerintah dan BI. File : //A: Pacific Link-Kolom Pakar.

Hutagalung., Djumahir., Ratnawati. 2011. Analisa Rasio Keuangan terhadap Kinerja Bank Umum di Indonesia. Jurnal Ekonomi dan Bisnis. Volume 11, No.1. Unviersitas Brawijaya. Malang.

Handayani, Puspita. 2005. Analisa Perbandingan Kinerja Bank dengan Rasio Keuangan. Tesis Magister Manajemen. Universitas Diponegoro. Semarang.

IDX. Laporan Keuangan Publikasi. www.idx.co.id diakses Mei 08 2014. Manado.

Kasmir. 2012. Manajemen Perbankan Edisi Revisi. PT Raja Grafindo Persada. Jakarta.

Machfoedz.,Mas'ud.,Payamta. 1999. Pengaruh Krisis Moneter pada Efisiensi Perusahaan Publik di Bursa Efek Jakarta. Jurnal Ekonomi dan Bisnis Indonesia. Volume 14, No.1. Hal 37-49.

Machfoedz, Ircham. 2006. Metodologi Penelitian. Fitrimaya. Yogyakarta.

Nasser.,Etty dan Aryati.,Titik. 2005. Model Analisis CAMEL untuk Memprediksi Financial Distress pada Sektor Perbankan yang Go Public. JAAI. Volume 4, No.2. Hal 111-127.

Peraturan Bank Indonesia Nomor 6/10/PBI/2004 tanggal 12 April 2004. Perihal Peringkat Komposit Setiap Faktor. Bank Indonesia. Jakarta.

Prasnanugraha, Ponttie. 2007. Analisis Pengaruh Rasio-rasio Keuangan Terhadap Kinerja Bank Umum di Indonesia. Tesis Magister Sains Akuntansi. Universitas Diponegoro. Semarang.

Republik Indonesia. Undang-Undang No. 10 tahun 1998 tentang Perbankan. Jakarta.

Rumondor, Risca. 2013. Perbandingan Kinerja Keuangan Bank MANDIRI, BNI, dan BRI Yang Terdaftar di Bursa Efek Indonesia. Jurnal EMBA. Universitas Sam Ratulangi. Manado.

Soendoro.,Hayati. 2001. Kinerja Keuangan Bank-Bank Beku Operasi, Take Over, Rekapitulasi dan Sehat tahun 1992-1998. Ventura. Volume 4, No.2, Hal 97-101.

Sunggono, Bambang. 2005. Pengantar Hukum Perbankan. CV Mandar Maju. Jakarta.

Surat Edaran Bank Indonesia Nomor 6/23/Intern DPNP tgl 31 Mei 2004. Perihal Pedoman Sistem Penilaian Tingkat Kesehatan Bank (CAMELS Rating). Bank Indonesia. Jakarta.

Surat Edaran Bank Indonesia Nomor 3/30/DPNP tanggal 14 Desember 2001. Lampiran Pedoman Perhitungan Rasio Keuangan. Bank Indonesia. Jakarta.

Suyatno, Thomas. 2007. Kelembagaan Perbankan. PT. Gramedia Pustaka Utama. Edisi Ketiga. Jakarta.

Utomo, Priyo. 2008. Pengaruh Non Performing Loan Terhadap Kinerja Keuangan Bank Berdasarkan Rasio Likuiditas, Solvabilitas, dan Profitabilitas Pada PT Bank Mandiri (PERSERO), Tbk. Tesis Magister Manajemen. Universitas Gunadarma. Jakarta. 